\title{
PReS-FINAL-2314: Anti-TNF alpha therapy for refractory childhood takayasu arthritis
}

\author{
B Koren ${ }^{1 *}$, Š Blazina² ${ }^{2}$ N Toplak², D Ključevšek ${ }^{2}$, T Avčin $^{2}$ \\ From 20th Pediatric Rheumatology European Society (PReS) Congress \\ Ljubljana, Slovenia. 25-29 September 2013
}

\section{Introduction}

Takayasu arteritis (TA) is a rare chronic granulomatous vasculitis of large vessels. Initial symptoms and signs are usually non-specific, therefore a high index of suspicion is needed to make a timely and correct diagnosis.

\section{Objectives}

To review our experience with treatment of children with TA.

\section{Methods}

We analysed patients data.

\section{Results}

In our centre we are currently treating two adolescents with TA. Patient 1 presented with arthralgia, anaemia and fatigue. Patient 2 demonstrated leg claudication. None of them had hypertension. In both of them vascular bruits and elevated inflammatory markers were present. Diagnosis was confirmed by magnetic resonance angiography (MRA). Both patients were initially treated with pulse methylprednisolone followed by a high dose oral corticosteroid in combination with methotrexate. Both patients achieved transient clinical and laboratory improvement with decreased inflammatory parameters after initial treatment. By tapering steroid therapy inflammatory parameters started to rise. Patient 2 also demonstrated less palpable leg pulses and persistent leg claudication. Followup MRA imaging demonstrated only partial improvement with persistent vascular changes in both patients. Because of incomplete disease control both patients were started on anti-tumor necrosis factor (TNF) alpha therapy with infliximab which resulted in good clinical and laboratory response with decreased inflammatory parameters.

${ }^{1}$ University medical centre, Maribor, Slovenia

Full list of author information is available at the end of the article

\section{Conclusion}

According to our experience anti-TNF alpha therapy appears to be a successful treatment approach in pediatric patients with refractory TA.

\section{Disclosure of interest}

None declared.

\section{Authors' details}

${ }^{1}$ University medical centre, Maribor, Slovenia. ${ }^{2}$ University medical centre, Ljubljana, Slovenia.

Published: 5 December 2013

doi:10.1186/1546-0096-11-S2-P304

Cite this article as: Koren et al.: PReS-FINAL-2314: Anti-TNF alpha

therapy for refractory childhood takayasu arthritis. Pediatric

Rheumatology 2013 11(Suppl 2):P304.
Submit your next manuscript to BioMed Central and take full advantage of:

- Convenient online submission

- Thorough peer review

- No space constraints or color figure charges

- Immediate publication on acceptance

- Inclusion in PubMed, CAS, Scopus and Google Scholar

- Research which is freely available for redistribution
() Biomed Central 